\title{
Kainate Receptor-Mediated Responses in the CA1 Field of Wild- Type and GluR6-Deficient Mice
}

\author{
Ingrid Bureau, ${ }^{1}$ Serge Bischoff, ${ }^{2}$ Steve F. Heinemann, ${ }^{3}$ and Christophe Mulle ${ }^{1}$ \\ ${ }^{1}$ Centre National de la Recherche Scientifique, Université Victor Segalen, Bordeaux 33076, France, 2Novartis, CH-4002, \\ Basel, Switzerland, and ${ }^{3}$ Molecular Neurobiology Laboratory, The Salk Institute for Biological Studies, \\ La Jolla, California 92037
}

Kainate receptors are abundantly expressed in the hippocampus. Mice with disruption of kainate receptor subunits allow the genetic dissection of the role of each kainate receptor subunits in the synaptic physiology of the hippocampus, as well as in excitotoxic processes. We have compared the action of domoate and kainate on CA1 pyramidal neurons in slices from wild-type and GluR6-/- mice. The difference in the amplitude of inward currents evoked by domoate and kainate between wild-type and GluR6-/- mice demonstrates the presence of functional kainate receptors in CA1 pyramidal neurons. Block of domoate-activated inward currents by the AMPA receptor antagonists 2,3-dihydroxy-6-nitro-7-sulfonyl-benzo(F)quinoxaline (1 $\mu \mathrm{M})$ and 1-(4-aminophenyl)-3-methylcarbamyl-4-methyl7,8-methylenedioxy-3,4-dihydro-5H-2,3-benzodiazepine) (GYKI $53655)(50 \mu \mathrm{M})$ is complete in GluR6-/- mice but only partial in wild-type mice. In the presence of GYKI 53655, kainate receptor activation dramatically increases the frequency of spontaneous IPSCs in CA1 pyramidal cells from wild-type, as well as GluR6-/-, mice. This results from the kainate receptormediated activation of a sustained inward current and an increased action potential firing in afferent GABAergic interneurons of the CA1 field. These effects are observed in wild-type, as well as GluR6-/-, mice. Kainate receptors also decrease the amplitude of evoked IPSCs in CA1 pyramidal cells by increasing synaptic failures in wild-type and GluR6-/- mice. These results indicate that in CA1 pyramidal cells, distinct subtypes of kainate receptors mediate several functionally antagonistic effects.

Key words: kainate receptors; GluR6 knock-out mouse; CA1 pyramidal cells; CA1 interneurons; NBQX; GYKI 53655
Glutamate is the major excitatory neurotransmitter in the vertebrate CNS. It acts on three major types of ligand-gated ion channels, which are defined by the agonists NMDA, AMPA, and kainate. The family of kainate receptors (KARs) is composed of five subunits (GluR5-GluR7, KA1-KA2) that can assemble to form functional channels but do not coassemble with subunits from the AMPA receptor (AMPAR) family (GluR1-GluR4) (Nakanishi, 1992; Seeburg, 1993; Hollmann and Heinemann, 1994; Bettler and Mulle, 1995). AMPARs and KARs can be activated by kainate and domoate. In many instances, it is not clear whether the effect of these agonists is mediated by the activation of AMPA or of KARs. Kainate and domoate evoke nondesensitizing currents from AMPAR channels but evoke fast desensitizing currents from recombinant and native KAR channels (Huettner, 1990; Lerma et al., 1993; Sahara et al., 1997; Wilding and Huettner, 1997).

Although KAR subunit genes are widely expressed throughout the brain (Wisden and Seeburg, 1993), the presence of functional KARs in the CNS and their role in synaptic transmission has long remained elusive. The lower abundance of these receptors com-

Received Aug. 10, 1998; revised Oct. 8, 1998; accepted Nov. 11, 1998.

This work was supported by grants and fellowships from the Centre National de la Recherche Scientifique, the French Ministère de la Recherche et de l'Enseignement Supérieur, the Fondation pour la Recherche Médicale, and the Région Aquitaine (all to C.M.), and from the National Institute of Neurological Diseases and Stroke and the McKnight foundation (both to S.F.H.). We thank Elizabeth Normand and Sabine Leonhard for their excellent technical assistance and Pablo Castillo for his thoughtful comments on this manuscript.

Correspondence should be addressed to Christophe Mulle, Unité Mixte de Recherche 5541, Centre National de la Recherche Scientifique, Université Victor Segalen, Bordeaux 33076, France.

Copyright (C) 1999 Society for Neuroscience $\quad 0270-6474 / 99 / 190653-11 \$ 05.00 / 0$ pared with AMPARs, the fast-desensitizing response to glutamate receptor agonists, and the lack of specific pharmacological tools have hampered the functional characterization of KARs. The development of selective antagonists for AMPARs (Paternain et al., 1995; Wilding and Huettner, 1995; Bleakman et al., 1996) and the characterization of selective agonist and antagonists for the GluR5 subunit (Clarke et al., 1997) has given a new development to the study of KARs in the brain. Hippocampus has been the focus of the majority of recent studies on the role of KARs. Taking advantage of 1-(4-aminophenyl)-3-methylcarbamyl4-methyl-7,8-methylenedioxy-3,4-dihydro-5H-2,3-benzodiazepine) (GYKI 53655) (LY30068), an antagonist of AMPARs that does not affect KARs, functional KARs have been characterized in hippocampal neurons in culture and in the slice preparation. The physiological properties of responses mediated by KARs in embryonic hippocampal neurons in culture (Lerma et al., 1993), which resemble those mediated by homomeric recombinant GluR6 receptors, show profound desensitization to kainate. In postnatal hippocampal neurons in culture, KAR-evoked currents show incomplete desensitization (Wilding and Huettner, 1997). In the slice preparation, bath application of kainate in the presence of GYKI 53655 activate large inward currents in CA3 neurons, suggesting that KARs in CA3 neurons do not show complete desensitization (Castillo et al., 1997). KARs can be synaptically activated at mossy fiber-CA3 synapses (Castillo et al., 1997; Vignes and Collingridge, 1997). Analysis of GluR6-deficient mice has demonstrated the implication of the GluR6 subunit in the high sensitivity of CA3 neurons to kainate and in synaptic transmission in the mossy fiber pathway (Mulle et al., 1998). KARs are also thought to modulate synaptic transmission by acting at a presynaptic site in CA3 and 
CA1 pyramidal cells (Represa et al., 1987; Chittajallu et al., 1996; Clarke et al., 1997; Rodriguez-Moreno et al., 1997; Kamiya and Ozawa, 1998).

CA1 pyramidal cells are known to be far less sensitive to kainate than CA3 pyramidal cells (Robinson and Deadwyler, 1981; Westbrook and Lothman, 1983). In the rat, kainate (1-5 $\mu \mathrm{M})$ only mildly affects membrane potential in CA1 pyramidal cells (Fisher and Alger, 1984; Clarke et al., 1997) and evokes inward currents of small amplitude (Castillo et al., 1997). However, KAR genes are abundant in the CA1 field. We have reexamined the question of the presence of functional KARs in CA1 pyramidal cells. For this purpose, we have tested the response of CA1 neurons to application of domoate and kainate in a slice preparation, and we have compared these responses in wild-type and GluR6-/- mice.

\section{MATERIALS AND METHODS}

Hippocampal slices (300- $\mu$ m-thick) were prepared from 13 - to 25 -d-old mice. Mice were killed by decapitation after cervical dislocation, and slices were cut from the whole forebrain in the sagittal plane in an ice-cold oxygenated solution. Slices were first kept for $1 \mathrm{hr}$ in oxygenated $\mathrm{HCO}_{3}-\mathrm{H}_{2} \mathrm{PO}_{4}$ buffered saline (see composition below) at $32^{\circ} \mathrm{C}$ and then kept at room temperature for up to $6 \mathrm{hr}$ before being transferred to the experimental setup.

CA1 neurons were visualized throughout the recording session with an upright microscope equipped with Nomarski optics (Axioscop; Zeiss, Oberkochen, Germany). Tight-seal whole-cell recordings were obtained from neurons visually identified as pyramidal cells or nonpyramidal cells according to their location in or outside the pyramidal cell layer. Recordings were performed at room temperature. The slice was continuously perfused with a physiological saline of the following composition (in mM): $125 \mathrm{NaCl}, 2.5 \mathrm{KCl}, 2 \mathrm{CaCl}_{2}, 1 \mathrm{MgCl}_{2}, 1.25 \mathrm{NaH}_{2} \mathrm{PO}_{4}, 26$ $\mathrm{NaHCO}_{3}$, and 25 glucose, pH 7.4 when bubbled with a mixture of $95 \%$ $\mathrm{O}_{2}$ and $5 \% \mathrm{CO}_{2}$. Whole-cell voltage-clamp experiments were performed with a Cs-based internal solution containing (in $\mathrm{mm}$ ): $140 \mathrm{CsCl}, 2$ $\mathrm{MgCl}_{2}, 1 \mathrm{CaCl}_{2}, 10$ EGTA, $10 \mathrm{HEPES}$, and $2 \mathrm{Na}-\mathrm{ATP}$. Recording patch electrodes were pulled from borosilicate glass and had resistances of 2.3-3.0 $\mathrm{M} \Omega$ when filled with a CsCl-based solution.

Whole-cell membrane currents were recorded with a computer-driven amplifier (EPC9; HEKA, Lambrecht, Germany). Access resistance (5-18 M $\Omega$ ) was regularly monitored. Extracellular recordings of action potentials from interneurons were made in the cell-attached configuration. IPSCs were evoked at $3 \mathrm{sec}$ intervals by applying short $(200 \mu \mathrm{sec})$ current pulses through an extracellular saline-filled pipette placed in stratum oriens. EPSCs were evoked by stimulating the Schaeffer collaterals at $10 \mathrm{sec}$ intervals with a pipette placed in the stratum radiatum.

Spontaneous synaptic currents and voltage data were filtered at $10 \mathrm{kHz}$ and acquired continuously on a computer disk using the Pulse program (HEKA). The detection and analysis of spontaneous synaptic currents were performed using Detectivent, a program written by N. Ankri (Ankri et al., 1994). Data were further analyzed using macros written for IGOR (Wavemetrix, Inc.). For the presentation of average values from several cells, averages are presented as mean \pm SE.

Pharmacological agents were delivered either by bath perfusion or by means of a multibarrel gravity-fed system composed of four to six capillaries, which was positioned just above the slice and could be moved laterally.

Most salts and chemicals were obtained from Sigma (St. Louis, MO). Domoate was purchased from Tocris Cookson (Bristol, UK). GYKI 53655 (LY300168) was a generous gift from Lilly Research Laboratories (Indianapolis, IN).

In situ hybridization. Adult male mice of different strains [129SvJ C57BL/6 mouse (The Jackson Laboratory, Bar Harbor, ME); hybrid 129SvJxC57BL/6; in-house inbred mouse Tif (MAG [Spf])], weighing $18-25 \mathrm{gm}$, were used. Animals were killed by decapitation, and the brains were carefully and rapidly removed and embedded into cryoglue (OCT; Miles, Elkhart, IN) for cryosectioning. Coronal sections (10- $\mu$ m-thick) were thaw-mounted onto slides precoated with poly-L-lysine (Electron Microscopy Sciences, Ft. Washington, PA). Consecutive sections were mounted on different slides allowing hybridization with each of the five KAR subunits. The sections from the $129 \mathrm{SvJ}$ mouse, taken at the level of the dorsal hippocampus, were used for the quantitative analysis. In this study, we have used riboprobes coding for GluR5 ( $5^{\prime}$ antisense, $656 \mathrm{bp}$ ), GluR6 ( $5^{\prime}$ antisense, $\left.997 \mathrm{bp}\right)$, GluR7 (5' antisense, 476bp), KA1 (5' antisense, 215bp), and KA2 ( $5^{\prime}$ antisense, 342bp). These riboprobes had been checked previously for specificity and used extensively for mapping studies in the basal ganglia (Bischoff et al., 1997). In situ hybridization histochemistry was performed as described previously. The only modification used was an increase of the final high-stringency posthybridization wash to $75-80^{\circ} \mathrm{C}$.

Quantitative analysis was performed on sections exposed to nuclear emulsion and counterstained with cresyl violet. The procedure uses a macro specifically written for this purpose with the help of the basic KS-400 software package (Kontron, Munich, Germany). The level of expression was measured in identified cells within the layers of the hippocampal formation and expressed as the percentage of the surface of each cell that is covered by silver grains. For this purpose, digitized images of microscope fields at $200 \times$ magnification at bright-field followed by dark-field illumination were imported via a CCD camera to a personal computer for analysis. Six to eight fields for each side of a section were processed for measurements. For each field, the clearly identifiable cells were circled by hand, but quantification was processed automatically. The individual cellular expression levels of the pooled fields were analyzed statistically for normal Gauss distribution, and data were expressed as mean $\pm \mathrm{SD}$ values. Almost all pyramidal cells in the CA1 and CA3 fields were included in the quantitation. A similar number of cells of the caudate putamen (primarily medium spiny neurons), adjacent to the hippocampal formation, was also examined for comparison purposes.

\section{RESULTS}

\section{Expression of KAR subunit genes in the mouse hippocampus}

In situ hybridization experiments with antisense RNA probe specific for the five KAR subunit genes were performed in 129Sv and C57Bl6 mice (Fig. 1) to compare with previous reports using oligonucleotides in the rat (Wisden and Seeburg, 1993). Macroscopic analysis reveals that GluR5 exhibits a punctated profile throughout the hippocampus, with no signal in the pyramidal and granule cell layers. GluR6 and KA2 are the most abundant subunits, with marked expression in the principal cell layers and the hilus (Egebjerg et al., 1991; Herb et al., 1992). GluR7 is primarily expressed in the granular layer of the dentate gyrus and in a few interneurons in the stratum oriens and stratum radiatum. KA1 is markedly expressed in the CA3 pyramidal layer but very weakly in the CA1 and dentate gyrus. To compare the level of expression of GluR6 in the CA1 and CA3 fields, we made quantitative measurements at the microscopic level (see Materials and Methods) (Fig. 2). At dark-field illumination, the spread of silver grains appears consistently less dense in the CA1 than in the CA3 field. Quantitative measurements reveal that the level of expression per cell is twice as high in CA3 $(40.3 \pm 13.2)$ than in CA1 $(20.0 \pm 9.7)$ pyramidal neurons. The expression level in CA3 was close to that in the medium spiny neurons of the caudate putamen (48.2 \pm 12.0$)$, which exhibits among the highest GluR6 expression levels within the brain (Bischoff et al., 1997). The GluR5 subunit was barely detectable in the pyramidal neurons of both CA1 and CA3. GluR5 was very highly expressed in most (but not all) interneurons identified by Nissl-staining within the molecular layers (stratum oriens and stratum radiatum) of both CA1 and CA3 fields. GluR6 also appears expressed in a number of these interneurons in both layers, although in fewer cells and with a lower level of expression.

\section{Selective activation of KARs by low concentrations of domoate and kainate}

Given the consistent expression of the GluR6 gene in CA1 pyramidal cells, we searched for the presence of GluR6-containing kainate responses in these neurons by comparing wild-type and 

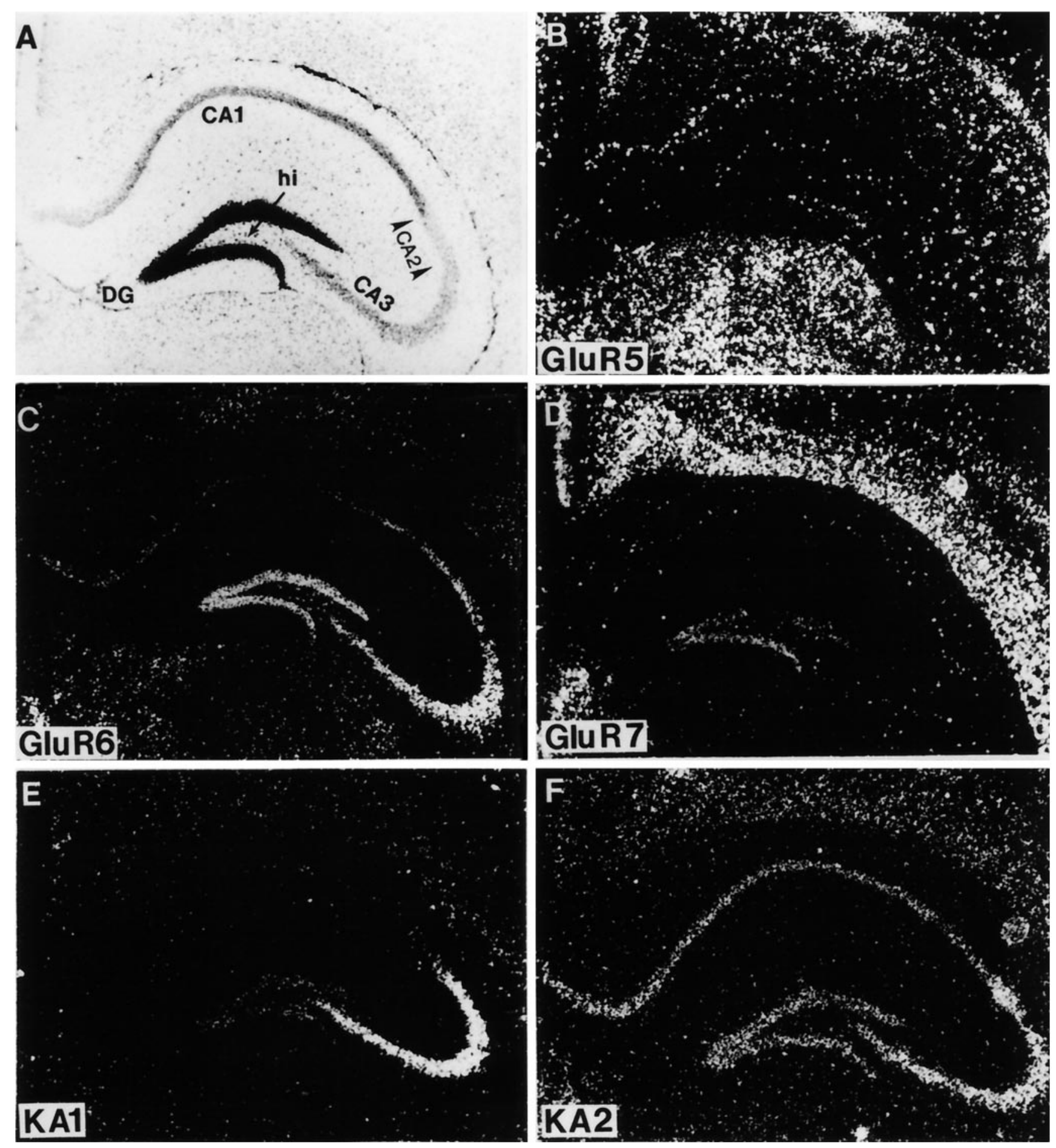

Figure 1. Mapping of the mRNA encoding the five KAR subunits in the anterior dorsal hippocampus of $129 \mathrm{SvJ}$ mouse brain as assessed with ${ }^{35} \mathrm{~S}$-labeled riboprobes. Photomicrographs were taken by the stereomicroscope $(10 \times)$ under bright-field $(A)$ or dark-field $(B-F)$ illumination. $A$ is a section processed for cresyl violet counterstaining. The dark-field representations in $B-F$ reveal considerable differences in the expression pattern of each KAR subunit.

GluR6-deficient mice (Mulle et al., 1998). We performed wholecell recordings from CA1 pyramidal cells and applied domoate and kainate to the slice. In the presence of TTX (500 nM), picrotoxin $(100 \mu \mathrm{M})$, and D,L-AP-5 $(100 \mu \mathrm{M})$, domoate activated a sustained inward current at concentrations as low as $200 \mathrm{~nm}(121 \pm 42 \mathrm{pA}$; $n=5)$ (Fig. $3 A)$ in wild-type but not in GluR6-/- mice $(n=5)$. At a concentration of $500 \mathrm{nM}$, domoate activated large inward currents in wild-type mice $(365 \pm 91 \mathrm{pA} ; n=4)$ and only small inward currents in GluR6-/- mice $(58 \pm 13 \mathrm{pA} ; n=7)$. Similarly, kainate activated a small inward current at a concentration of $3 \mu \mathrm{M}$ $(31.8 \pm 13.0 \mathrm{pA} ; n=4)$ in wild-type but not in GluR6-/- mice $(n=5)$ (Fig. $3 B)$. The amplitude of the currents evoked by $10 \mu \mathrm{M}$ kainate was also significantly larger in wild-type $(480.3 \pm 198.0 \mathrm{pA}$; $n=4)$ than in GluR6-/- mice $(73.0 \pm 10.6 \mathrm{pA} ; n=4)$. A significant difference was thus observed in the amplitudes of inward currents evoked by low concentrations of domoate and kainate 
GluR5
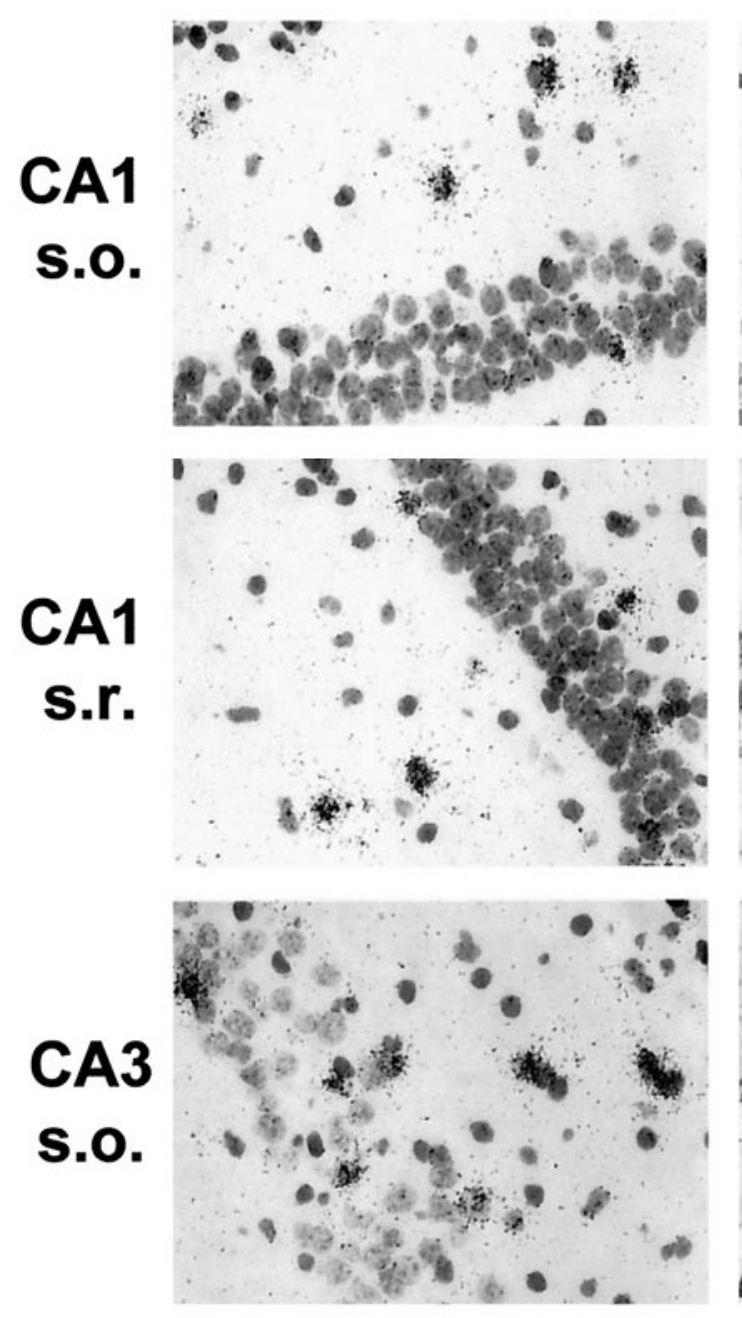

Figure 2. Cellular expression of GluR5 and GluR6 subunits at high magnification $(200 \times)$. Expression of GluR5 and GluR6 subunits in the pyramidal cell layers and interneurons of the stratum oriens (s.o.) and stratum radiatum (s.r.) of CA1 and CA3 fields. GluR5 is highly expressed in the interneurons of the nonpyramidal layer, but some strongly labeled cells appear also among the pyramidal neurons. GluR6 is primarily expressed in the pyramidal cells, but scattered dimly labeled cells are also seen in the stratum oriens and radiatum of both $\mathrm{CA} 1$ and $\mathrm{CA} 3$ fields.

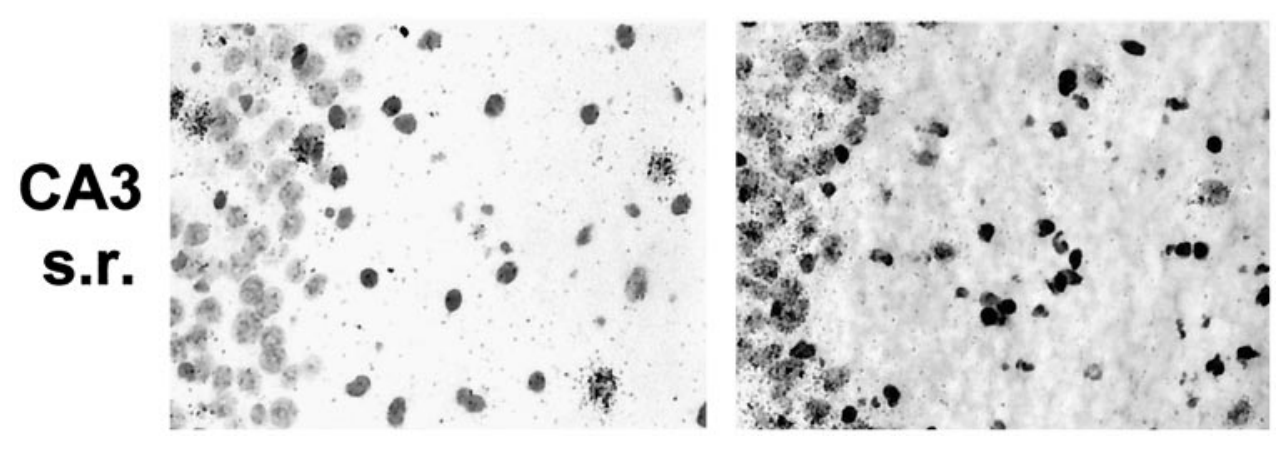

between wild-type and GluR6-/- mice (for each agonist concentration, $p<0.01$; Mann-Whitney $U$ test) (Fig. $3 B$ ). These results indicate the presence of functional GluR6-containing KARs in CA1 pyramidal cells. These data also define the range of concentrations for which domoate and kainate predominantly activate a KAR-mediated response.

Antagonism of AMPARs and KARs by 2,3-dihydroxy-6nitro-7-sulfonyl-benzo(F)quinoxaline and GYKI 53655

We compared the effects of the competitive antagonist 2,3-dihydroxy-6-nitro-7-sulfonyl-benzo(F)quinoxaline (NBQX) and the noncompetitive antagonist GYKI 53655 on domoate-activated inward currents in wild-type and GluR6-/- mice. Quinoxa- linediones have initially been characterized as selective antagonists of AMPARs (Sheardown et al., 1990). Previous work on DRG and hippocampal neurons in culture has suggested that quinoxaline derivatives, such as CNQX, are only slightly more selective antagonists for AMPARs than for KARs (Paternain et al., 1996; Wilding and Huettner, 1996). However, NBQX was reported to be far more potent against AMPAR response in acutely isolated Purkinje cells than on recombinant GluR6 receptors (Bleakman et al., 1996). The use of KAR subunit-deficient mice should prove useful for determining the selectivity of these agents for native AMPARs and KARs in brain slices. To test for the potential use of NBQX as a selective AMPAR antagonist, we 
A wild-type
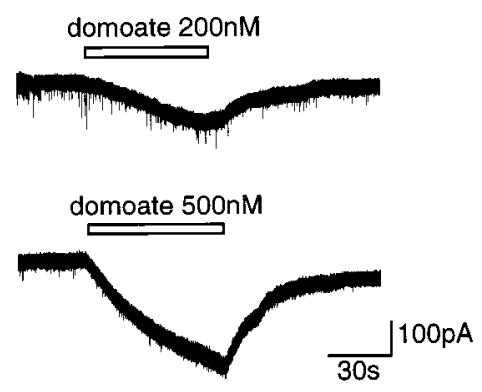

B

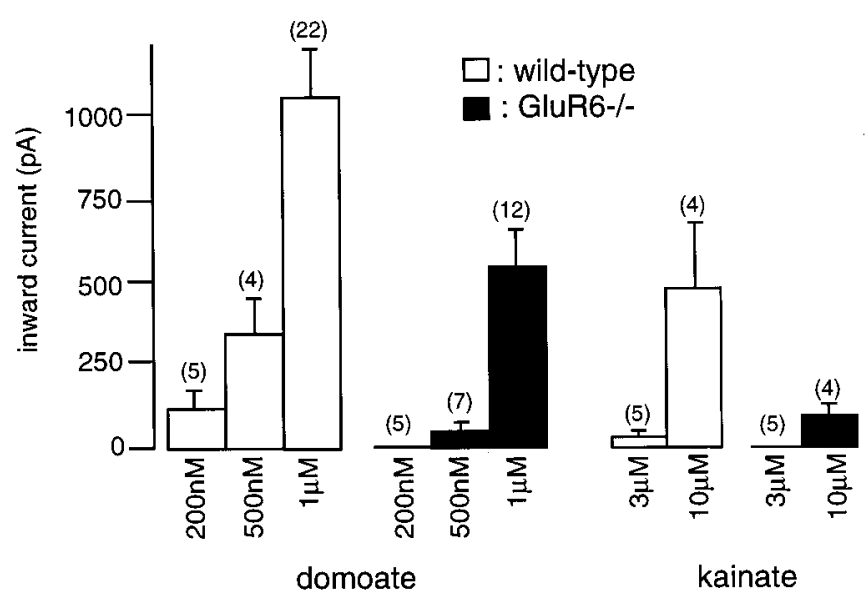

have compared the effect of this antagonist in CA1 and CA3 pyramidal cells from wild-type and GluR6-/- mice. In GluR6-/- mice, NBQX $(1 \mu \mathrm{M})$ blocked the AMPAR-mediated currents evoked by domoate $(1 \mu \mathrm{M})$ in CA1 (100\% inhibition; $n=$ 6 cells) (Fig. 4) and CA3 (>95\% inhibition; $n=3$ cells) (Fig. 5) pyramidal cells. In wild-type mice, NBQX (1 $\mu \mathrm{M})$ only partially blocked inward currents activated by domoate $(1 \mu \mathrm{M})$ in CA1 pyramidal cells (amplitude of the residual current, $335 \pm 35 \mathrm{pA}$; $n=9$ ) (Fig. 4). This residual current, which was blocked by high concentration of NBQX $(100 \mu \mathrm{M})$ and was absent in GluR6-/mice, is likely mediated by the activation of GluR6-containing KARs. In addition, in CA3 pyramidal cells from wild-type mice, NBQX $(1 \mu \mathrm{M})$ did not significantly block the large inward current activated by domoate $(500 \mathrm{nM})(1214 \pm 176 \mathrm{pA} ; n=4 ; p>0.2$; Mann-Whitney $U$ test) (Fig. 5), which is mediated by KAR activation (as evidenced by the absence of such a current in GluR6-/- mice). These results imply that NBQX, under certain experimental conditions, is a fairly selective AMPAR antagonist that can be used to unmask KAR responses evoked by domoate and kainate in CA1 and CA3 pyramidal cells. Because NBQX is a competitive antagonist, it might prove ineffective in blocking AMPAR-mediated responses evoked by higher concentrations of AMPAR agonists. We thus tested the effects of NBQX on EPSCs evoked by stimulating the Schaeffer collaterals in CA1 pyramidal cells from wild-type and GluR6-deficient mice in which AMPARs are activated by millimolar concentrations of glutamate. NBQX, at a concentration of $1 \mu \mathrm{M}$, blocked evoked EPSCs by $86 \pm 2(n=4)$ and $91 \pm 2 \%(n=4)$ in wild-type and GluR6-deficient mice, respectively (Fig. 6A). Evoked EPSCs were blocked by $>99 \%$ in wild-type $(n=4)$ and GluR6-deficient $(n=4)$ mice by $3 \mu \mathrm{M}$ NBQX. These data make it unlikely that the inward current re-
Figure 3. Comparison of the response of CA1 pyramidal cells to domoate and kainate in wild-type and GluR6-/mice. $A$, Whole-cell currents activated by domoate in wildtype (left) and GluR6-/- (right) mice by domoate (open horizontal bar). At a concentration of $200 \mathrm{nM}$, domoate activated a small inward current in wild-type but not in GluR6-/- mice. At a concentration of $500 \mathrm{~nm}$, domoate activated an inward current in GluR6-/- mice, which was much smaller than in wild-type mice. $B$, Pooled data of the average amplitudes of inward currents activated by domoate and kainate in wild-type (open bars) and GluR6-/- ( filled bars) mice. The bar graphs show mean \pm SEM values. Numbers in parentheses represent the number of cells tested. Membrane holding potential was $-70 \mathrm{mV}$. All solutions were applied using a multibarrel perfusion system and contained TTX (500 nM), D,L-AP-5 (50 $\mu \mathrm{M})$, and picrotoxin $(100 \mu \mathrm{M})$.

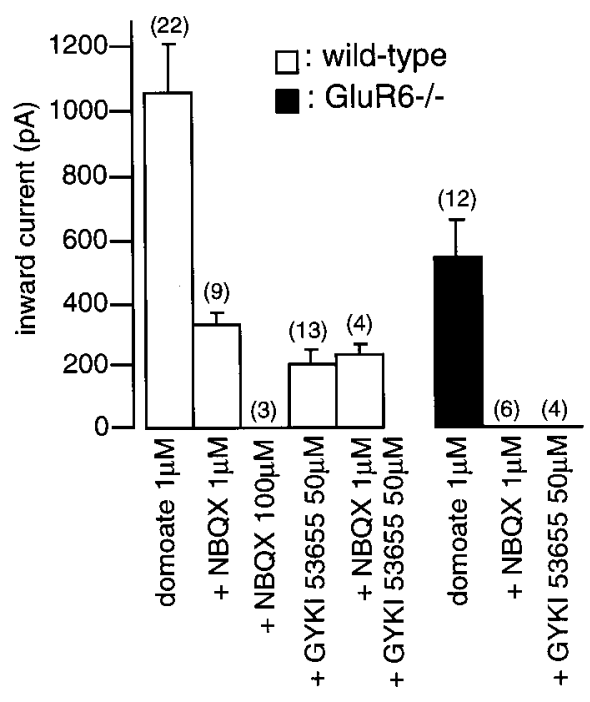

Figure 4. Antagonism of domoate-activated inward currents in CA1 pyramidal cells by NBQX and GYKI 53655 in wild-type and GluR6-/mice. Pooled data of the mean amplitude of currents activated by domoate $(1 \mu \mathrm{M})$ in the presence and absence of NBQX or GYKI 53655. The bar graphs show mean \pm SEM values. Numbers in parentheses represent the number of cells tested. All solutions were applied using a multibarrel perfusion system and contained TTX (500 nM), D,L-AP-5 (50 $\mu \mathrm{M})$, and picrotoxin $(100 \mu \mathrm{M})$. 
Figure 5. Antagonism of domoate-activated inward currents in CA3 pyramidal cells by NBQX in wild-type and GluR6-/- mice. A, Whole-cell currents activated by domoate in the presence and absence of NBQX in wild-type (left traces) and GluR6-/- (right traces) mice. Domoate (500 nM) activated an inward current in wild-type but not in GluR6-/- mice. In wild-type mice, this current was only slightly inhibited by NBQX $(1 \mu \mathrm{M})$. In GluR6-/- mice, domoate $(1 \mu \mathrm{M})$ activated a small current, which was almost completely blocked by NBQX $(1 \mu \mathrm{M})$. $B$, Pooled data of the mean amplitude of currents activated by domoate $(500 \mathrm{nM}$ or $1 \mu \mathrm{M})$ in the presence and absence of NBQX. The bar graphs show mean \pm SEM values. Numbers in parentheses represent the number of cells tested. All solutions were bath-applied and contained TTX (500 nM) and picrotoxin (100 $\mu \mathrm{M})$.
A

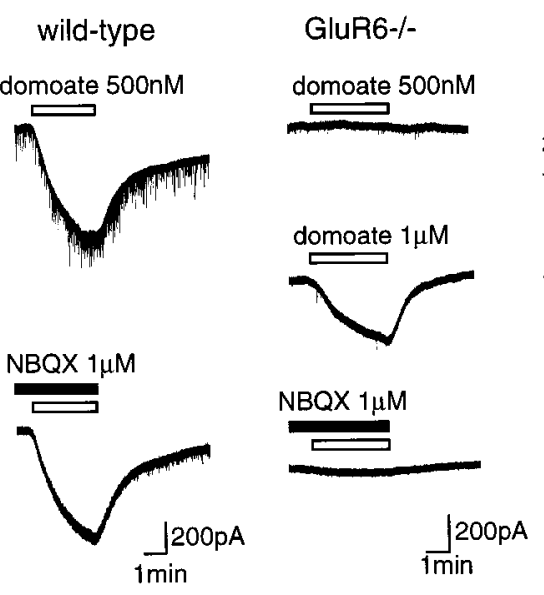

B

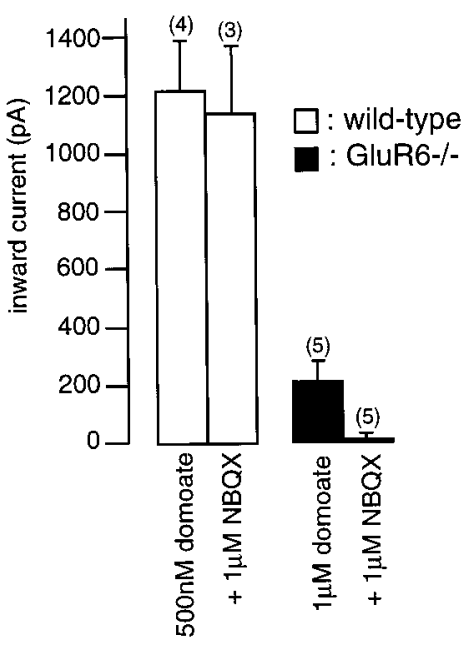

Figure 6. Antagonism of evoked EPSCs in CA1 pyramidal cells by NBQX and GYKI 53655 in wildtype and GluR6-/- mice. EPSCs were evoked by focal stimulations of the Schaeffer collaterals. Each trace represents the average of 10 consecutive recordings. $A$, Evoked EPSCs were primarily blocked by 1 $\mu \mathrm{M}$ NBQX and completely blocked by $3 \mu \mathrm{M}$ NBQX in both wild-type and GluR6-/- mice. $B$, GYKI $53655(50 \mu \mathrm{M})$ totally blocked evoked EPSCs in wildtype mice. All solutions were bath-applied and contained picrotoxin $(100 \mu \mathrm{M})$ and D,L-AP-5 $(50 \mu \mathrm{M})$.

A NBQX

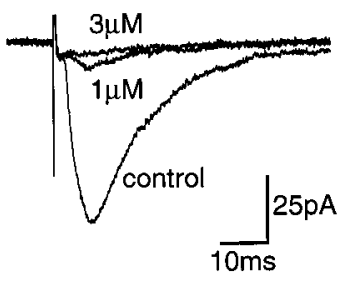

wild-type
B GYKI 53655

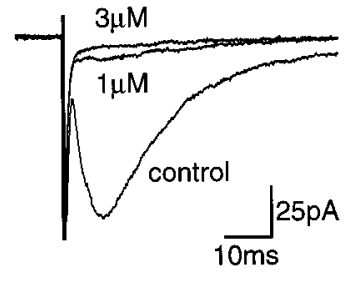

GluR6-/-

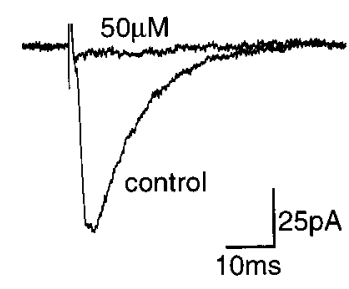

wild-type corded in the presence of domoate $(1 \mu \mathrm{M})$ and NBQX $(1 \mu \mathrm{M})$ could be caused by, in part, the displacement of NBQX by glutamate released from unclamped neurons in the slice.

GYKI 53655 (LY30068), a selective noncompetitive antagonist of AMPARs, has proven useful in the functional characterization of KARs (Paternain et al., 1995; Wilding and Huettner, 1995). In the presence of GYKI $53655(50 \mu \mathrm{M})$, domoate evoked a sustained inward current in CA1 pyramidal cells from wild-type mice $(199 \pm 40 \mathrm{pA} ; n=13)$, whereas no current was detected in GluR6-/- mice $(n=4)$ (Fig. 4). This finding confirms the presence of functional KARs in CA1 pyramidal cells. It must be noted that the KAR-mediated inward current recorded in the presence of GYKI 53655 was on average slightly smaller than that recorded in the presence of NBQX $(p<0.02$; Mann-Whitney $U$ test). Experiments in which NBQX $(1 \mu \mathrm{M})$ and NBQX $(1 \mu \mathrm{M})$ plus GYKI $53655(50 \mu \mathrm{M})$ were applied successively showed that GYKI 53655 further decreased the amplitude of inward currents activated by domoate by $26 \pm 3 \%(n=4)$. Although the slice preparation does not allow a quantitative pharmacological evaluation of this aspect, our results suggest that GYKI 53655 might partly block steady-state KAR-mediated responses in CA1 pyramidal cells. In agreement with previous studies in the rat (Castillo et al., 1997), we also found that GYKI 53655 (50 $\mu \mathrm{M})$ completely blocked EPSCs evoked in CA1 pyramidal cells by stimulation of the Schaeffer collaterals (Fig. 6B).

\section{Activation of KARs increases the rate of spontaneous GABAergic synaptic currents in CA1 pyramidal cells in both wild-type and GluR6-/- mice}

In the presence of NBQX $(1 \mu \mathrm{M})$ or both NBQX $(1 \mu \mathrm{M})$ and GYKI $53655(50 \mu \mathrm{M})$, KAR activation produced two distinct effects in CA1 pyramidal cells from wild-type mice. Domoate (500 nM) activated an inward current likely caused by the direct activation of KARs, because a similar inward current was observed in the presence of TTX and picrotoxin. In all cells tested, domoate and kainate $(3 \mu \mathrm{M})$ also markedly increased the frequency of spontaneous postsynaptic currents in a rapid and reversible manner (Fig. 7). These synaptic currents were blocked by picrotoxin but not by antagonists selective for NMDA receptors (D,L-AP-5) and AMPARs (NBQX and GYKI 53655) and were thus GABAergic IPSCs. On average, spontaneous IPSC frequency, increased by a factor of $3.0 \pm 0.2(n=6)$ and $1.7 \pm 0.2$ $(n=5)$ after bath application of $500 \mathrm{nM}$ domoate and $3 \mu \mathrm{M}$ kainate, respectively. We often noted the occurrence of largeamplitude IPSCs rapidly after onset of domoate application, which were not observed during the control period (Fig. 8). A more detailed examination (Fig. $7 B$ ) showed that domoate increased the frequency of IPSCs displaying a wide range of amplitudes.

In GluR6-/- mice, domoate (500 nM) did not activate any significant inward current (Fig. $8 A$ ), in keeping with the results obtained in the presence of picrotoxin and TTX. However, in the presence of GYKI $53655(50 \mu \mathrm{M})$, domoate increased the rate of spontaneous IPSCs (Fig. 8 $A$ ) from a basal level of $9.5 \pm 3.8 \mathrm{~Hz}$ $(n=5)$ to a maximal level of $16.1 \pm 6 \mathrm{~Hz}(n=5)$. On average, spontaneous IPSC frequency increased by a factor of $2.0 \pm 0.2$ $(n=5)$. NBQX, at a concentration of $50 \mu \mathrm{M}$, totally blocked domoate-induced increase of IPSC frequency (Fig. 8B). This effect of domoate on spontaneous IPSC frequency is thus probably mediated by the activation of KARs. This receptor differs 
A
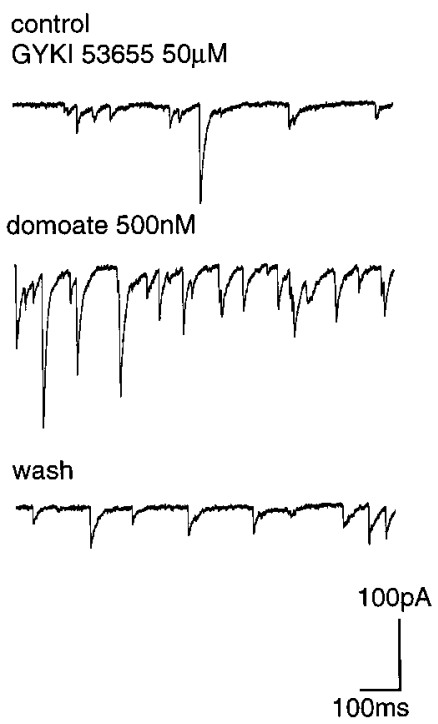

B
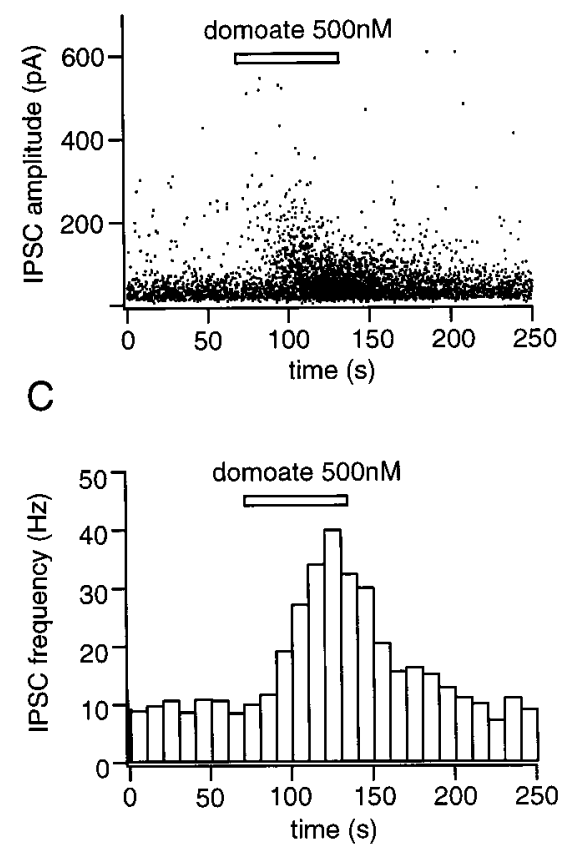

Figure 7. Activation of KARs increases IPSC frequency in CA1 pyramidal cells from wild-type mice. $A$, Samples of continuous recording of spontaneous IPSCs in a CA1 pyramidal cell from a wild-type mouse. Domoate (500 nM) in the presence of GYKI $53655(50 \mu \mathrm{M})$ lead to a reversible increase in IPSC frequency. $B$, Plot for the same cell of the amplitude of spontaneous IPSCs. $C$, Plot for the same cell of the mean frequency of IPSCs detected during $10 \mathrm{sec}$ sample intervals against time. The slice was bathed with physiological saline supplemented with $4 \mathrm{~mm} \mathrm{CaCl}_{2}, 4 \mathrm{~mm} \mathrm{MgCl}_{2}$, and $100 \mu \mathrm{M}$ D,L-AP-5. from KARs mediating the inward current in CA1 pyramidal cells, because it is still observed in GluR6-/- mice.

\section{Functional KARs in interneurons from the CA1 field}

Increase in the rate of spontaneous IPSCs in CA1 pyramidal cells is probably caused by an increased action potential discharge in GABAergic neurons afferent to CA1 pyramidal cells. We thus checked for the presence of functional KARs activated under conditions of bath application of KAR agonists in interneurons of the CA1 field. Voltage-clamp whole-cell recordings were obtained from visually identified neurons located in both stratum oriens (five cells in wild-type mice, five cells in GluR6-/- mice) and stratum radiatum (eight cells in wild-type mice, seven cells in GluR6-/- mice). As illustrated in Figure 9A, domoate $(1 \mu \mathrm{M})$, applied in the presence of GYKI $53655(50 \mu \mathrm{M})$ or a low concentration of NBQX (1 $\mu \mathrm{M})$ (data not shown) evoked a sustained inward current in almost all neurons tested in both wild-type and GluR6-/- mice. In the presence of GYKI $53655(50 \mu \mathrm{M})$, the amplitude of the inward current evoked by domoate $(1 \mu \mathrm{M})$ ranged from 40 to $290 \mathrm{pA}$ in wild-type mice (average amplitude, $182 \pm 22 \mathrm{pA} ; n=8$ ) and from 20 to $320 \mathrm{pA}$ in GluR6-/- mice (average amplitude, $204 \pm 42 \mathrm{pA} ; n=5$ ). Functional KARs are thus found on CA1 interneurons, but the response evoked by activation of these KARs is not abolished in the GluR6-/- mice, indicating that they are composed of subunits different from GluR6.

The effect of KAR activation on action potential discharge was studied in identified interneurons of the CA1 stratum oriens and stratum radiatum using the cell-attached configuration. Under our control conditions, in the presence of GYKI 53655, interneurons were generally silent. Bath application of domoate (500 nM) or kainate $(2 \mu \mathrm{M})$ lead to a rapid and slowly reversible increase in action potential firing (Fig. 9B) in both wild-type (six of seven cells) and GluR6-/- (five of six cells) mice. On average, domoate $(500 \mathrm{~nm})$ increased action potential firing to a value of $18 \pm$ 5 and $10 \pm 2 \mathrm{~Hz}$ in wild-type and GluR6-/- mice, respectively. These results clearly indicate that KARs activate an inward current in CA1 interneurons, which leads to depolarization and action potential discharge, an effect that fully explains the increase in spontaneous IPSC frequency observed in CA1 pyramidal cells.

\section{KARs downregulate evoked IPSCs in both wild-type and GluR6-/- mice}

In rat CA1 pyramidal cells, kainate is known to decrease evoked GABAergic synaptic transmission (Sloviter and Damiano, 1981; Fisher and Alger, 1984), an effect recently shown to be mediated by activation of KARs (Clarke et al., 1997; Rodriguez-Moreno et al., 1997). We thus examined this latter effect of kainate in wild-type and GluR6-/- mice. IPSCs were evoked in mouse CA1 pyramidal cells by focal stimulation in the stratum oriens in the presence of GYKI $53655(50 \mu \mathrm{M})$ and D,L-AP-5 $(100 \mu \mathrm{M})$. After a stable control period, perfusion of the slice with domoate $(500 \mathrm{nM})$ or kainate $(3 \mu \mathrm{M})$ (for $1-2 \mathrm{~min}$ ) lead in most cases to a rapid and reversible decrease in the amplitude of evoked IPSCs. The extent of this decrease varied from cell to cell and in a given cell could differ when displacing the stimulating electrode to stimulate a different set of afferent GABAergic fibers. We regularly observed a striking increase in the number of failures (Fig. $10 A$ ), consistent with a presynaptic effect of KAR activation. On average, the amplitude of the evoked IPSCs decreased by $59 \pm$ $8 \%(n=7$; range, $36-96 \%)$ with $3 \mu \mathrm{M}$ kainate. This decrease in evoked synaptic transmission took place despite the above mentioned increase in spontaneous IPSC frequency, which was clearly seen in all cells (Fig. 10B, second trace). In GluR6-/- mice, kainate $(3 \mu \mathrm{M})$ decreased evoked GABAergic synaptic transmission to a similar extent. An increase in the number of failures was a common feature (Fig. 10), which was observed in addition to an increase in the frequency of spontaneous IPSCs. On average, kainate $(3 \mu \mathrm{M})$ decreased evoked IPSC amplitude by $56 \pm 12 \%$ $(n=7$; range, $0-94 \%)$, a value not statistically different from that reported in wild-type mice. In contrast with the rapid and profound effects of these agonists on the frequency of spontaneous 
A
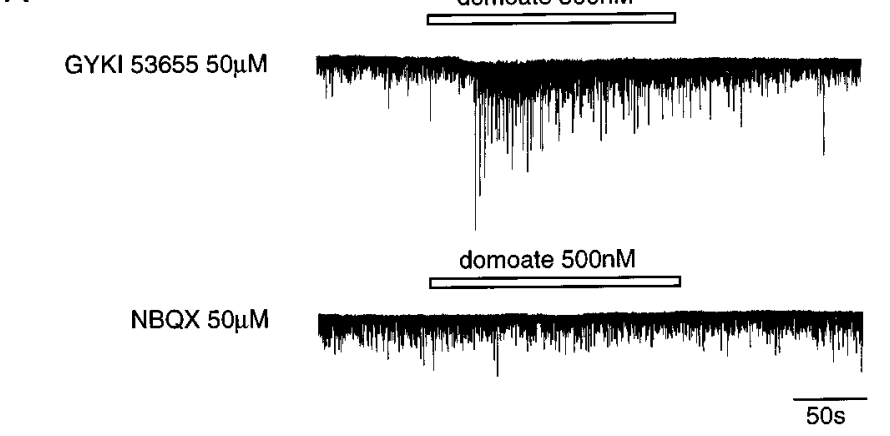

B
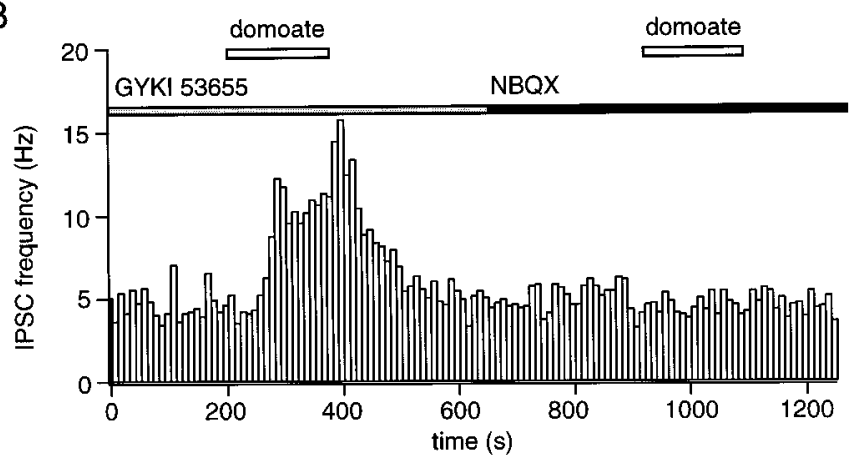

Figure 8. KAR-mediated increase in spontaneous IPSC frequency in CA1 pyramidal cells of GluR6-/- mice. A, Top trace, Sample of continuous recording of spontaneous IPSCs in a pyramidal cell of a GluR6-/mouse. Domoate $(500 \mathrm{nM})$ in the presence of GYKI $53655(50 \mu \mathrm{M})$, applied during the time indicated by the horizontal bars, increased spontaneous IPSC frequency. Bottom trace, In the same cell, addition of $50 \mu \mathrm{M}$ NBQX completely blocked the effects of domoate. $B$, Plot for the same cell of the mean frequency of spontaneous IPSCs detected during $10 \mathrm{sec}$ sample intervals against time. Open horizontal bars, The time during which domoate was applied; gray horizontal bar, the time during which GYKI $53655(50 \mu \mathrm{M})$ was applied; closed horizontal bar, the time during which NBQX $(50 \mu \mathrm{M})$ was applied. The slice was bathed with physiological saline supplemented with $4 \mathrm{mM} \mathrm{CaCl}_{2}, 4 \mathrm{mM} \mathrm{MgCl}_{2}$, and $100 \mu \mathrm{M}$ D,L-AP-5.

IPSCs and on the amplitude of evoked IPSCs, we did not observe any rapid and striking change in the frequency of miniature IPSCs (mIPSCs) recorded in the presence of TTX (500 nM) after superfusion with KAR agonists. A moderate decrease in mIPSC frequency $(10-30 \%)$ was observed in only three of nine cells for domoate $(1 \mu \mathrm{M})$ and kainate $(10 \mu \mathrm{M})$ after prolonged application of the agonist ( $>4 \mathrm{~min})$ (data not shown).

\section{DISCUSSION}

Mice with disrupted KAR subunit genes offer the possibility to clarify the specific role of KAR subtypes in synaptic transmission and in the neurotoxic effects of kainate. In the present study, we demonstrate the presence of at least two distinct subtypes of KARs in pyramidal cells and interneurons of the CA1 field of the hippocampus by comparing the electrophysiological responses to kainate and domoate of neurons from wild-type and GluR6-/mice. Despite the well known downregulation of evoked GABAergic synaptic transmission by KAR agonists, we also show that KAR agonists increase spontaneous IPSC frequency in CA1 pyramidal cells by increasing action potential discharge in presynaptic GABAergic interneurons.
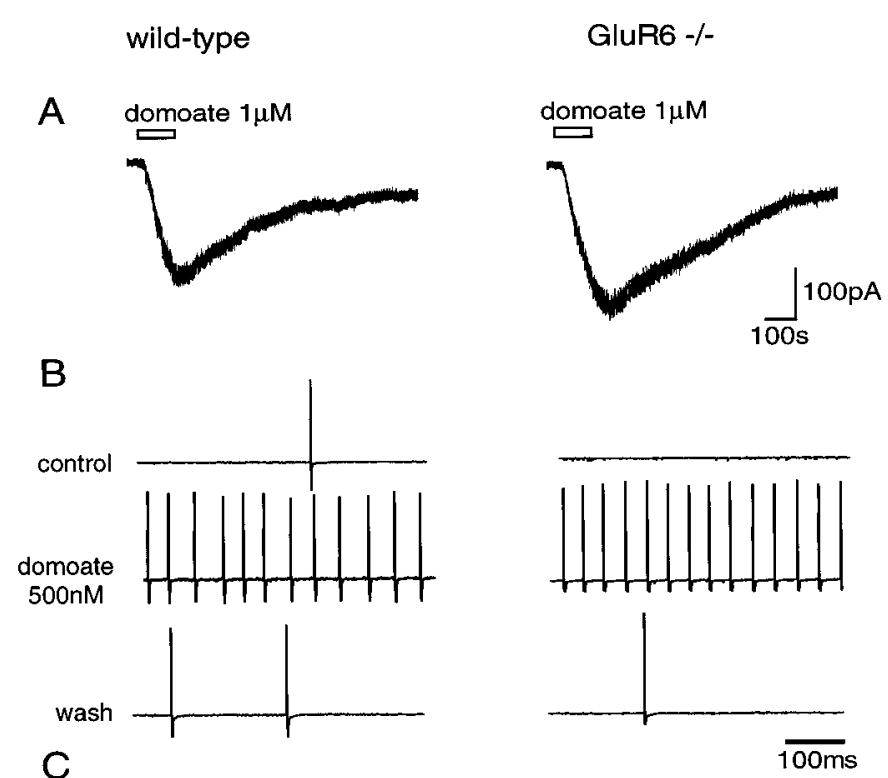

C
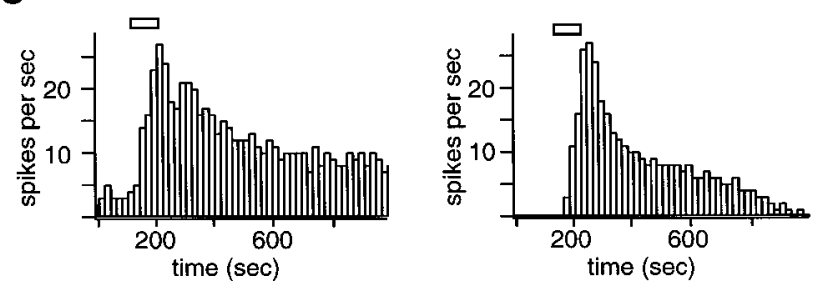

Figure 9. Functional KARs in CA1 stratum oriens interneurons from wild-type and GluR6-/- mice. Left panels, Wild-type mice. Right panels, GluR6-/- mice. A, Domoate $(1 \mu \mathrm{M})$ activated an inward current in stratum oriens interneurons of both wild-type and GluR6-/- mice in the presence of GYKI $53655(50 \mu \mathrm{M})$. B. Samples of continuous recording of action potential firing activity in stratum oriens interneurons. In both wild-type and GluR6-/- mice, domoate (500 nM) induced a reversible increase in spike frequency in interneurons in the presence of GYKI $53655(50 \mu \mathrm{M}) . C$, Plots for the same cells of the mean frequency of spikes detected during $20 \mathrm{sec}$ sample intervals against time. Open horizontal bars indicate the time during which domoate (500 nM) was applied.

\section{Functional KARs in CA1 pyramidal cells and interneurons}

The demonstration of the presence of functional KARs has been made in only a few neuronal populations. In the CNS, KARs were first characterized in hippocampal neurons in culture (Lerma et al., 1993). Significant differences are observed in the properties of KARs recorded in neurons cultured from embryonic or postnatal rats (Lerma et al., 1993; Wilding and Huettner, 1997). It is important to demonstrate the presence of functional KARs in identified populations of hippocampal neurons, which express specific combinations of KAR subunit genes (Wisden and Seeburg, 1993; present study). KARs participate in synaptic transmission at the mossy fiber-CA3 synapse (Castillo et al., 1997; Vignes and Collingridge, 1997). The analysis of GluR6-/mice has indicated that functional KARs in CA3 pyramidal cells involved in synaptic transmission are assembled from the GluR6 subunit (Mulle et al., 1998). CA3 pyramidal cells are far more sensitive to KAR agonists than CA1 pyramidal cells (Robinson and Deadwyler, 1981; Westbrook and Lothman, 1983; Castillo et al., 1997). In fact, it is not known whether functional KARs are present in CA1 pyramidal cells. In recent studies using GYKI 53655 to block AMPARs, no clear evidence was given for inward 
A

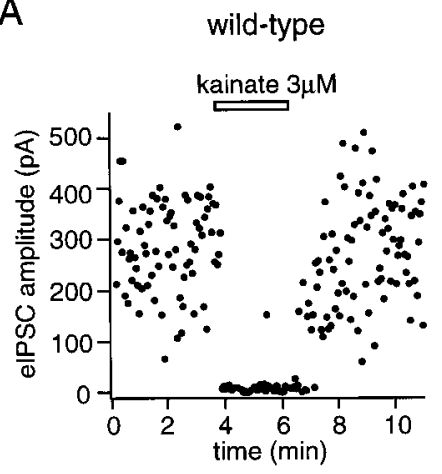

B
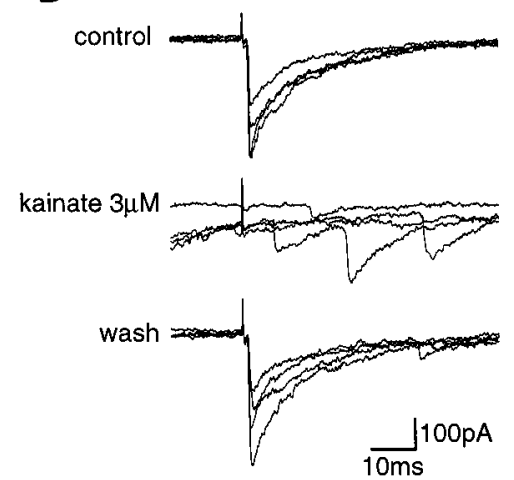

GluR6-/-
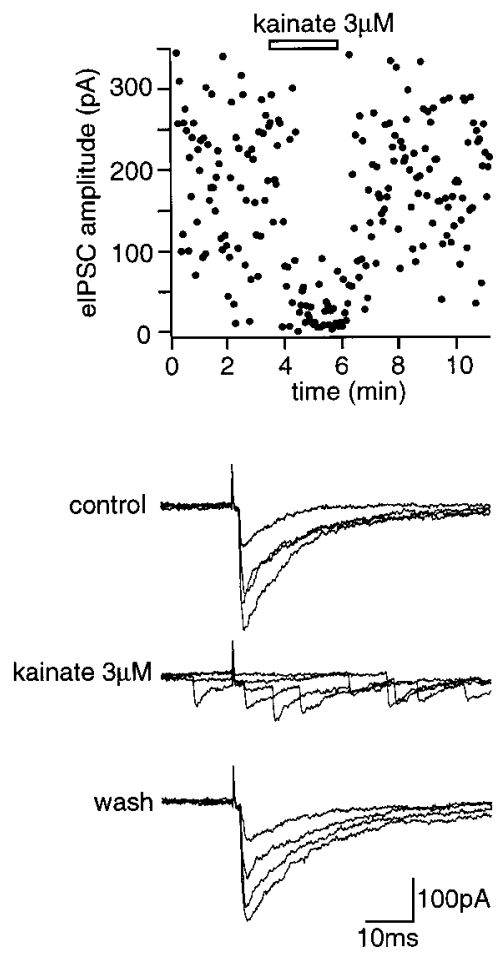

Figure 10. KAR-mediated effect on evoked IPSCs in CA1 pyramidal cells from wild-type and GluR6 $-/-$ mice. Left panels, Wild-type mouse. Right panels, GluR6-/- mouse. A, Plots of the amplitude of IPSCs evoked in a CA1 pyramidal cell by focal stimulations in CA1 stratum oriens. Kainate (3 $\mu \mathrm{M})$ in the presence of GYKI $53655(50 \mu \mathrm{M})$, applied during the time indicated by the horizontal bars, induced a reversible increase in the failure rate of evoked IPSCs in both wildtype and GluR6-/- mice. B, For the same cell, superposition of four consecutive recordings. Kainate $(3 \mu \mathrm{M})$ lead to a reversible increase in spontaneous IPSC frequency and a failure rate of evoked IPSCs in the presence of GYKI 53655 $(50 \mu \mathrm{M})$ in wild-type and GluR6 $-/-$ mice. currents activated by KAR agonists in CA1 pyramidal cells (Clarke et al., 1997; Rodriguez-Moreno et al., 1997).

CA1 pyramidal cells, like CA3 pyramidal cells, are known to express the GluR6 subunit gene (Egebjerg et al., 1991; Wisden and Seeburg, 1993), although a quantitative analysis of the expression of the GluR6 subunit gene revealed a lower abundance of the GluR6 transcripts in CA1 cells compared with CA3 pyramidal cells (present study). We have thus compared the response of CA1 pyramidal cells to application of domoate or kainate in hippocampal slices from wild-type and GluR6-/- mice. In contrast with previous studies on cultured hippocampal neurons, the responses to kainate and domoate that we observed in the slice preparation represent the steady-state receptor activity. Steadystate activation of KAR is, however, an important parameter in understanding the excitotoxic effects of KAR agonists. A clearcut difference in the amplitude of inward currents activated by low concentrations of kainate and domoate was observed between wild-type and GluR6-/- CA1 pyramidal cells, indicating the presence of functional GluR6-containing KARs in CA1 pyramidal cells. The inward current evoked by activation of KARs is of smaller amplitude in CA1 pyramidal cells ( $3 \mu \mathrm{M}$ kainate, 32 pA) than in CA3 pyramidal cells ( $3 \mu \mathrm{M}$ kainate, 678 pA) (Mulle et al., 1998). Furthermore, kainate activates detectable inward currents at concentrations of kainate as low as $300 \mathrm{~nm}$ in CA3 pyramidal cells. This large difference (an order of magnitude) in the sensitivity to kainate between CA1 and CA3 pyramidal cells is in good agreement with earlier reports (Robinson and Deadwyler, 1981; Castillo et al., 1997). Several interpretations can account for this difference. First, functional KARs are less abundant in CA1 than in CA3 pyramidal cells, as suggested by the lower expression of the GluR6 gene in CA1 pyramidal cells. An additional explanation for the difference in sensitivity is that
KARs in CA3 and CA1 have different functional and pharmacological properties. An important factor in determining the amplitude of a KAR-mediated response in the slice preparation lies in the desensitization properties and in the level of the steady-state current. Recombinant KARs generated from homomeric GluR6 subunit displays pharmacological and physiological properties distinct from those of recombinant KARs generated by coexpression of GluR6 and KA2 (Herb et al., 1992; Partin et al., 1993; Howe, 1996). The properties of heteromeric GluR6-KA1 receptors have not been analyzed (but see Partin et al., 1993). It remains possible that coassembly of GluR6 with either KA1 or KA2 subunits produces KARs with distinct pharmacological and desensitization properties. Slower desensitization of heteromeric GluR6-KA1 receptors could for instance account for the large difference in the response to bath application of kainate between CA 3 and CA1 pyramidal neurons. Our data provide preliminary evidence in favor of a difference in the pharmacological properties of KARs in CA1 and CA3 pyramidal cells. For instance, at concentrations in which the agonists act primarily on KARs, kainate $(3 \mu \mathrm{M})$ activates an inward current 20 times larger in CA3 than in CA1 pyramidal cells, whereas the difference with domoate $(500 \mathrm{nM})$ is only by a factor 3 .

We show that the GluR5 gene is highly expressed in mouse hippocampal interneurons of stratum oriens and stratum radiatum, as reported for the rat (Wisden and Seeburg, 1993). We show the presence of functional KARs in CA1 interneurons from wild-type, as well as GluR6-/-, mice. In agreement with this result, GluR6 transcripts were found only at a low level in both stratum oriens and stratum radiatum neurons. KARs present on hippocampal interneurons are thus likely assembled from the GluR5 subunit. These findings demonstrate the diversity of KAR subtypes within the hippocampus. 


\section{KARs and the regulation of synaptic inhibition in CA1 pyramidal cells}

Synaptic inhibition in the CA1 region of the hippocampus is generated by an heterogeneous group of local circuit interneurons located in stratum oriens and stratum radiatum (Freund and Buzsaki, 1996). An important finding of the present work is that activation of KARs increases the frequency of spontaneous IPSCs in CA1 pyramidal cells. This effect is explained by a sharp increase in the rate of action potentials in afferent GABAergic interneurons. Action potentials are triggered by the depolarizing action of KARs present in these neurons. In GluR6-/- mice, KAR activation also increases the rate of spontaneous IPSCs in CA1 pyramidal cells and the rate of action potential discharge in CA1 interneurons. A small but significant difference $(p<0.05)$, however, was observed in the effect of domoate on spontaneous IPSC frequency between wild-type and GluR6-/- mice. There is no simple explanation for this result. A direct excitation of CA1 interneurons by $\mathrm{CA} 3$ pyramidal cells could be partly involved in the depolarization of interneurons but would require activation of a glutamate receptor insensitive to GYKI 53655 and D,L-AP-5. Alternatively, GluR6-containing KARs could be present in a few interneurons, as suggested by our in situ hybridization experiments. It must be noted, however, that no significant difference in the amplitude of inward currents evoked by domoate in CA1 interneurons was found.

Kainate has long been known to decrease evoked GABAergic synaptic transmission in CA1 pyramidal cells (Sloviter and Damiano, 1981; Fisher and Alger, 1984), an effect mediated by the activation of KARs (Clarke et al., 1997; Rodriguez-Moreno et al., 1997). In rat CA1 pyramidal cells, kainate increases the failure rate of evoked IPSCs and attenuates mIPSC frequency, suggestive of a presynaptic action of KARs (Rodriguez-Moreno et al., 1997). In accordance with these results, KAR activation decreases the amplitude of evoked IPSCs in both wild-type and GluR6-/- mice. This finding indicates that this effect of kainate is not mediated indirectly by a retrograde signal that could be released after activation of postsynaptic (GluR6-containing) KARs. It also adds to the pharmacological evidence involving GluR5 as a KAR subunit involved in the process (Clarke et al., 1997). However, the localization of GluR5-containing KARs at an axonal-presynaptic location is at the moment speculative. In contrast with results obtained in the rat (Rodriguez-Moreno et al., 1997), we have observed a moderate attenuation in the frequency of mIPSCs in only a minority of CA1 pyramidal cells tested. The reason for this difference is not clear but might be attributed to a species difference. A number of authors have reported concomitantly an increase in spontaneous IPSC frequency and an increase in failure rate (Llano and Marty, 1995). The decrease in IPSC amplitude and probability could be a direct consequence of the large increase in action potential firing of afferent interneurons, leading to refractoriness of axon terminal regions. The increase in failure rate might explain the difference between the increase in the frequency of spontaneous IPSCs recorded in CA1 pyramidal cells and the larger increase in action potential firing in GABAergic afferent interneurons. Nevertheless, the main conclusion is that activation of KARs in interneurons predominantly provides an inhibitory drive to CA1 pyramidal cells.

The physiological output of the activation of KARs in CA1 pyramidal cells is thus the result of a balance between opposite mechanisms: a direct depolarization of pyramidal cells and an indirect inhibition caused by excitation of afferent GABAergic interneurons. These findings need to be placed in the general context of the hippocampal network. Although these results do not directly adress the way in which KARs are physiologically activated, they are nevertheless important for studies on kainateinduced excitotoxicity given the possibility it offers to differentially affect the distinct mechanisms using subunit-specific pharmacological agents.

Note added in proof: While this article was being reviewed, two papers were published [Cossart R, Esclapez M, Hirsch JC, Bernard C, Ben-Ari Y (1998) Nature Neuroscience 1:470-478; Frerking M, Malenka RC, Nicoll R (1998) Nature Neuroscience 1:479-486] showing that, similar to our results, kainate receptor activation in rat CA1 interneurons increases tonic inhibition in CA1 pyramidal cells.

\section{REFERENCES}

Ankri N, Legendre P, Faber DS, Korn H (1994) Automatic detection of spontaneous synaptic responses in central neurones. J Neurosci Methods 52:87-100.

Bettler B, Mulle C (1995) AMPA and kainate receptors. Neuropharmacology 34:123-139.

Bischoff S, Barhanin J, Bettler B, Mulle C, Heinemann S (1997) Spatial distribution of kainate receptor subunit mRNA in the mouse basal ganglia and ventral mesencephalon. J Comp Neurol 379:541-562.

Bleakman D, Ballyk BA, Schoepp DD, Palmer AJ, Bath CP, Sharpe EF, Woolley ML, Bufton HR, Kamboj RK, Tarnawa I, Lodge D (1996) Activity of 2,3-benzodiazepines at native rat and recombinant human glutamate receptors in vitro: stereospecificity and selectivity profiles. Neuropharmacology 35:1689-1702.

Castillo PE, Malenka RC, Nicoll RA (1997) Kainate receptors mediate a slow postsynaptic current in hippocampal CA3 neurons. Nature 388:182-186.

Chittajallu R, Vignes M, Dev KK, Barnes JM, Collingridge GL, Henley JM (1996) Regulation of glutamate release by presynaptic kainate receptors in the hippocampus. Nature 379:78-81.

Clarke VRJ, Ballyk BA, Hoo KH, Mandelzys A, Pellizzari A, Bath CP, Thomas J, Sharpe EF, Davies CH, Ornstein PL, Schoepp DD, Kamboj RK, Collingridge GL, Lodge D, Bleakman D (1997) A hippocampal GluR5 kainate receptor regulating inhibitory synaptic transmission. Nature 389:599-603.

Egebjerg J, Bettler B, Hermans-Borgmeyer I, Heinemann S (1991) Cloning of a cDNA for a glutamate receptor subunit activated by kainate but not AMPA. Nature 351:745-748.

Fisher R, Alger B (1984) Electrophysiological mechanisms of kainic acid-induced epileptiform activity in the rat hippocampal slice. J. Neurosci 4:1312-1323.

Freund T, Buzsaki G (1996) Interneurons of the hippocampus. Hippocampus 6:347-470.

Herb A, Burnashev N, Werner P, Sakmann B, Wisden W, Seeburg PH (1992) The KA-2 subunit of excitatory amino acid receptor shows widespread expression in brain and forms ion channels with distantly related subunits. Neuron 8:775-785.

Hollmann M, Heinemann S (1994) Cloned glutamate receptors. Annu Rev Neurosci 17:31-108.

Howe J (1996) Homomeric and heteromeric ion channels formed from the kainate-type subunits GluR6 and KA2 have very small but different unitary conductances. J Neurophysiol 76:510-519.

Huettner (1990) Glutamate receptor channels in rat DRG neuronsactivation by kainate and quisqualate and blockade of desensitization by Con-A. Neuron 5:255-266.

Kamiya H, Ozawa S (1998) Kainate receptor-mediated inhibition of presynaptic $\mathrm{Ca}^{2++}$ influx and EPSP in area CA1 of the rat hippocampus. J Physiol (Lond) 509:833-846.

Lerma J, Paternain AV, Naranjo JR, Mellstrom B (1993) Functional kainate selective glutamate receptors in cultured hippocampal neurons. Proc Natl Acad Sci USA 90:11688-11692.

Llano I, Marty A (1995) Presynaptic metabotropic regulation of inhibitory synapses in rat cerebellar slices. J Physiol (Lond) 486:163-176. 
Mulle C, Andreas S, Pérez-Otaño I, Dickinson-Anson H, Castillo PE, Bureau I, Maron C, Gage FH, Mann JR, Bettler B, Heinemann SF (1998) Altered synaptic physiology and reduced susceptibility to kainate induced seizures in GluR6-deficient mice. Nature 392:601-604.

Nakanishi N (1992) Molecular diversity of glutamate receptors and implications for brain function. Science 258:597-603.

Partin K, Patneau D, Winters C, Mayer M, Buonanno A (1993) Selective modulation of desensitization at AMPA versus kainate receptors by cyclothiazide and concanavalin A. Neuron 11:1069-1082.

Paternain A, Morales M, Lerma J (1995) Selective antagonism of AMPA receptor unmasks kainate receptor-mediated responses in hippocampal neurons. Neuron 14:185-189.

Paternain AV, Vicente A, Nielsen EO, Lerma J (1996) Comparative antagonism of kainate-activated kainate and AMPA receptors in hippocampal neurons. Eur J Neurosci 8:2129-2136.

Represa A, Tremblay E, Ben-Ari Y (1987) Kainic binding sites in the hippocampal mossy fibers: localization and plasticity. Neuroscience 20:739-748.

Robinson JH, Deadwyler SA (1981) Kainic acid produces depolarization of CA3 pyramidal cells in the in vitro hippocampal slice. Brain Res 221:117-127.

Rodriguez-Moreno A, Herrera O, Lerma J (1997) Kainate receptors presynaptically downregulate GABAergic inhibition in the rat hippocampus. Neuron 19:893-901.

Sahara Y, Noro N, Iida Y, Soma K, Nakamura Y (1997) Glutamate receptor subunits GluR5 and KA-2 are coexpressed in rat trigeminal ganglion neurons. J Neurosci 17:6611-6620.

Seeburg PH (1993) The molecular biology of mammalian glutamate receptor channels. Trends Neurosci 14:297-303.

Sheardown M, Nielsen E, Hansen A, Jacobsen P, Honoré T (1990) 2,3-Dihydroxy-6-nitro-7-sulfamoyl-benzo(F)quinoxaline: a neuroprotectant for cerebral ischemia. Science 247:571-574.

Sloviter R, Damiano B (1981) On the relationship between kainic acidinduced epileptiform activity and hippocampal neuronal damage. Neuropharmacology 20:1001-1011.

Vignes M, Collingridge GL (1997) The synaptic activation of kainate receptors. Nature 388:179-182.

Westbrook G, Lothman E (1983) Cellular and synaptic basis of kainic acid-induced hippocampal epileptiform activity. Brain Res 273:97-109.

Wilding T, Huettner J (1997) Activation and desensitization of hippocampal kainate receptors. J Neurosci 17:2713-2721.

Wilding TJ, Huettner JE (1995) Differential antagonism of alpha-amino3-hydroxy-5-methyl-4-isoxazolepropionic acid-preferring and kainatepreferring receptors by 2,3-benzodiazepines. Mol Pharmacol 47:582-587.

Wilding TJ, Huettner JE (1996) Antagonist pharmacology of kainateand alpha-amino-3-hydroxy-5-methyl-4-isoxazolepropionic acidpreferring receptors. Mol Pharmacol 49:540-546.

Wisden W, Seeburg P (1993) A complex mosaic of high-affinity kainate receptors in rat brain. J Neurosci 13:3582-3598. 